\title{
Loan to Deposit Ratio, Capital Adequacy Ratio, Non Performing Loan, Size dan Return On Assets Bank Perkreditan Rakyat di Provinsi Daerah Khusus Ibukota Jaya
}

Erni Yulianti ${ }^{1}$, Muhammad Yusuf ${ }^{2}$

${ }^{1}$ Universitas Pancasila, Jl. Srengseng Sawah, Jagakarsa, Jakarta Selatan, 12640

${ }^{2}$ STIE Indonesia Banking Scholl, Jl. Kemang Raya No. 35, Kemang Raya, Jakarta Selatan 12730

\section{INFO ARTIKEL}

JEL Classsification:

G21

M40

L25

Keywords:

loan to deposit ratio, capital adequacy ratio, return on assets, non performing loa.

\section{ABSTRACT}

This study aims to examine and analyze the effect of loan to deposit ratio, capital adequacy ratio, non performing loan and size to return on assets in rural bank of special areas of the capital jaya province, registered at bank Indonesia period of december 2015-december 2016. Sample which is used in this research as many as 13 rural banks that routinely report its progress to bank Indonesia. The results showed that the loan to deposit ratio and capital adequacy ratio did not affect the return on assets. Non-performing loans negatively affect return on assets, while the size has a positive effect on return on assets. Future research can be re-tested by adding the variable because the ability of independent variables affect the return on assets is moderate, so it is still possible to add variables in the model. The sample can be expanded for rural banks in Indonesia so that the results can be generalized to all rural banks in Indonesia.

\begin{abstract}
ABSTRAK
Penelitian ini bertujuan untuk menguji dan menganalisis pengaruh loan to deposit ratio, capital adequacy ratio, non performing loan dan size terhadap return on assets pada bank perkreditan rakyat wilayah provinsi daerah khusus ibukota jaya, yang terdaftar di bank Indonesia periode triwulan bulan desember 2015-desember 2016. Sampel yang digunakan dalam penelitian ini sebanyak 13 bank perkreditan rakyat yang secara rutin melaporkan perkembangannya pada bank Indonesia. Hasil penelitian menunjukkan bahwa loan to deposit ratio dan capital adequacy ratio tidak berpengaruh terhadap return on assets. Non performing loan berpengaruh negatif terhadap return on asset, sedangkan size berpengaruh positif terhadap return on asset. Riset mendatang dapat dilakukan pengujian ulang dengan menambah variabel karena kemampuan variabel independent mempengaruhi return on assets tergolong sedang, sehingga masih dimungkinkan menambah variabel di dalam model. Sample dapat diperluas untuk bank perkreditan rakyat di Indonesia agar hasil penelitian dapat digeneralisasi untuk seluruh bank perkreditan rakyat di Indonesia.
\end{abstract}

\section{Pendahuluan}

Bank adalah entititas yang memiliki akuntabilitas publik signifikan mengingat kegiatan utamanya adalah menghimpun dana pihak ketiga untuk kemudian disalurkan.
Profitabilitas menjadi salah satu kemampuan perusahaan untuk memperoleh laba selama periode tertentu (Munawir, 2010). Diharapkan bank mampu menjaga profitabilitas tetap stabil,

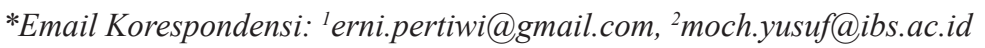


sehingga bank mampu mendapat dana dari pihak ketiga dan mampu meningkatkan kepercayaan masyarakat untuk menyimpan kelebihan dana pada bank. Sebagaimana dipaparkan oleh Agustiningrum $(2012,887)$ penting bagi bank menjaga profitabilitasnya tetap stabil bahkan meningkat untuk memenuhi kewajiban kepada pemegang saham, meningkatkan daya tarik investor dalam menanamkan modal, dan meningkatkan kepercayaan masyarakat untuk menyimpan kelebihan dana yang dimiliki pada bank.

Kepercayaan dan loyalitas pemilik dana terhadap bank merupakan faktor yang sangat membantu dan mempermudah pihak manajemen bank untuk menyusun strategi bisnis yang baik. Sebaliknya para pemilik dana yang kurang menaruh kepercayaan kepada bank yang bersangkutan, maka loyalitasnya pun juga sangat tipis, hal ini sangat tidak menguntungkan bagi bank yang bersangkutan karena para pemilik dana ini sewaktu-waktu dapat menarik dananya dan memindahkannya ke bank lain (Azwir, 2006). Hal ini diharapkan dengan menjaga profitabilitas bank, menjaga kesinambungan dan perkembangan pada bank itu sendiri, sehingga pemilik dana tidak menarik dananya untuk dipindahkan ke bank lain. Hal ini disebabkan adanya kepercayaan pemilik dana kepada bank sehingga loyalitas sangat tinggi. Semakin tinggi rasio dana pihak ketiga, maka semakin baik tingkat kepercayaan masyarakat terhadap bank yang bersangkutan. Adapun dana pihak ketiga diperoleh dengan menjumlahkan giro, tabungan dan deposito (Bambang Sudiyatno \& Jati Suroso, 2010:126). Ukuran profitabilitas pada industri perbankan yang digunakan pada umumnya adalah capital adequacy ratio, non performing loan, size dan loan to deposit ratio (Sari, Puspita, 2009).

Return on assets digunakan untuk mengetahui kemampuan bank menghasilkan keuntungan secara relatif dibandingkan dengan nilai total assetnya. Return on assets diperoleh berdasarkan perbandingan (rasio) laba sebelum pajak (earning before tax) selama 12 bulan terakhir terhadap rata-rata volume usaha dalam periode yang sama. return on assets merupakan kemampuan dari modal yang yang diinvestasikan ke dalam seluruh aktiva perusahaan untuk menghasilkan keuntungan. Semakin tinggi laba yang dihasilkan, maka semakin tinggi pula return on assets. Rasio ini penting bagi bank karena rasio ini menunjukan tingkat efisiensi pengelolaan aktiva. return on assets merupakan rasio antara laba bersih sebelum pajak terhadap total aktiva bank (Riyadi, Selamat, 2006:137). Semakin besar return on assets menunjukan kinerja keuangan semakin baik, karena tingkat kembalian (return) semakin besar (Husnan, Suand, 1998). Tingkat profitabilitas merupakan indikator yang paling tepat untuk mengukur kinerja bank. Ukuran profitabilitas yang digunakan pada industri perbankan adalah return on assets (Sofyan, Sofriza 2003). Adapun pokok permasalahan yang ada di bank perkreditan rakyat antara lain: dengan besar kecilnya ukuran perusahaan loan to deposit ratio, capital adequacy ratio, non performing loan sangat mempengaruhi tingkat profitabilitas. Dalam studi kasus pada bank perkreditan rakyat karena pertumbuhan yang sangat pesat akhirakhir ini dan sangat dibutuhkan serta membantu perekonomian masyarakat khususnya usaha mikro kecil menengah. Dari data research gap hasil penelitian fluktuatif (signifikan dan tidak signifikan), sehingga penulis ingin mengetahui secara jelas di bank perkreditan rakyat wilayah Provinsi Daerah Khusus Ibukota Jaya. Return on assets rata-rata bank perkreditan rakyat selama desember 2015-desember 2016 di wilayah provinsi daerah khusus ibukota jaya mengalami peningkatan yang dari $2,69 \%$ pada bulan desember 2015 menjadi $4,23 \%$ di bulan maret 2016. Return on assets di bulan juni 2016 mengalami penurunan menjadi $2,15 \%$, namun meningkat kembali pada bulan september 2016 sebesar 3,23\% dan peningkatan dibulan desember 2016 sebesar 4,62\%. 
Jika pihak bank perkreditan rakyat dapat menjaga kinerjanya dengan baik, terutama tingkat return on assets dengan baik, terutama tingkat profitabilitas yang tinggi serta dapat memenuhi ketentuan prudential banking dengan baik, maka kemungkinan nilai return on assets dan jumlah dana dari pihak ketiga yang berhasil dikumpulkan akan ikut naik. Kenaikan tersebut merupakan naiknya kepercayaan masyarakat kepada bank yang bersangkutan.

Capital adequacy ratio digunakan untuk mengukur kecukupan modal yang dimiliki bank untuk menunjang aktiva yang mengandung atau menghasilkan resiko, misalnya kredit yang diberikan. Semakin tinggi capital adequacy ratio, maka semakin kuat kemampuan bank tersebut untuk menanggung resiko dari setiap kredit atau aktiva produktif yang berisiko. Jika nilai capital adequacy ratio tinggi (sesuai dengan ketentuan bank Indonesia 8\%) berarti bahwa bank tersebut mampu membiayai operasional bank, dan keadaan yang menguntungkan tersebut dapat memberikan kontribusi yang cukup besar bagi profitabilitas bank, yaitu return on assets bank yang bersangkutan. Capital adequacy ratio ratarata bank perkreditan rakyat di wilayah provinsi daerah khusus ibukota jaya, diatas diperoleh sebesar $24,08 \%$ pada bulan desember 2015 pada bulan maret 2016 turun sebesar 23,38\%, pada bulan juni 2016 turun kembali sebesar $21,38 \%$ dan kembali turun menjadi 20,85\% pada bulan september 2016. Namun capital adequacy ratio mengalami peningkatan $22,00 \%$ pada bulan desember 2016. Tinggi rendahnya capital adequacy ratio suatu bank perkreditan rakyat dipengaruhi oleh 2 faktor utama, yaitu besarnya modal yang dimiliki bank dan jumlah aktiva tertimbang menurut resiko yang dikelola oleh bank tersebut. Hal ini disebabkan penilaian terhadap faktor permodalan didasarkan pada rasio antara modal sendiri terhadap aktiva tertimbang menurut resiko. Semakin tinggi nilai capital adequacy ratio mengindikasikan bahwa bank telah mempunyai modal yang cukup baik dalam menunjang kebutuhannya serta menanggung resiko yang ditimbulkannya termasuk di dalamnya resiko kredit.

Loan to deposit ratio rata-rata bank perkreditan rakyat di wilayah provinsi daerah khusus ibukota jaya terlihat loan to deposit ratio megalami penurunan sebesar $81,00 \%$ pada bulan desember 2015 menjadi 79,77\% pada bulan maret 2016, mengalami kenaikan kembali pada bulan juni 2016 menjadi 80,23\%. Tetap pada september 2016 sebesar $80,23 \%$ dan turun kembali secara singnifikan pada bulan desember 2016 menjadi $73,77 \%$. Loan to deposit ratio digunakan untuk mengukur kemampuan bank tersebut mampu membayar hutang-hutangnya dan membayar kembali kepada deposannya, serta dapat memenuhi permintaan kredit yang diajukan. Loan to deposit ratio adalah rasio antara seluruh jumlah kredit yang diberikan terhadap dana pihak ketiga. Besarnya jumlah kredit yang disalurkan akan menentukan keuntungan bank. Jika bank tidak mampu menyalurkan kredit sementara dana yang terhimpun banyak, maka akan menyebabkan bank tersebut rugi (Kasmir, 2008).

Rasio non performing loan digunakan untuk mengukur kemampuan manajemen bank dalam mengelola kredit bermasalah yang diberikan oleh bank. Risiko kredit yang diterima oleh bank merupakan salah satu risiko usaha bank, yang diakibatkan dari ketidakpastian dalam pengembaliannya atau yang diakibatkan dari tidak dilunasinya kembali kredit yang diberikan oleh pihak bank kepada debitur. Semakin tinggi rasio ini, maka akan semakin buruk kualitas kredit bank yang menyebabkan jumlah kredit bermasalah semakin besar dan menyebabkan kerugian, sebaliknya jika semakin rendah non performing loan, maka laba atau profitabilitas bank, yaitu return on assets tersebut akan semakin meningkat. Peningkatan rata-rata non performing loan sebesar $8.15 \%$ pada bulan desember 2015 dan mengalami peningkatan $8,23 \%$ pada bulan maret 2016, penurunan non performing loan pada bulan juni pada angka $6,62 \%$ dan naik kembali sebesar $6,69 \%$ pada 
bulan september 2016. Pada bulan desember 2016 terlihat penurunan sebesar $6,15 \%$.

Pertumbuhan kredit yang cukup tinggi belakangan ini merupakan salah satu penyebab terjadinya krisis likuiditas bank perkreditan rakyat, dikarenakan ekspansi kredit yang bergerak cepat tetapi tidak diikuti dengan kecepatan pertumbuhan dana masyarakat. Rasio pertumbuhan kredit dimaksudkan untuk mengukur seberapa besar upaya bank perkreditan rakyat dalam menyalurkan kredit dan hal ini terkait dengan fungsi bank perkreditan rakyat sebagai lembaga penghimpunan dana masyarakat dan menyalurkan kembali ke masyarakat dalam bentuk kredit. Pada tahun 2015, banyak permasalahan terjadi dalam bank perkreditan rakyat, diantaranya non performing loan yang cenderung terus meningkat dan juga masalah permodalan. Meningkatnya non performing loan akan mengurangi jumlah modal bank perkreditan rakyat karena pendapatan yang diterima bank perkreditan rakyat digunakan untuk menutupi non performing loan yang tinggi. Untuk menghadapi krisis finansial, bank perkreditan rakyat harus memperkuat modal dan meningkatkan kualitas penyaluran kredit. Non performing loan atau kredit bermasalah merupakan salah satu indikator kunci utama menilai kinerja fungsi bank perkreditan rakyat. Salah satu fungsi bank adalah sebagai lembaga intermediasi atau penghubung antara pihak yang memiliki kelebihan dana dengan pihak yang membutuhkan dana. Bank Indonesia menetapkan bahwa rasio kredit bermasalah adalah sebesar $5 \%$. Selama ini beberapa bank perkreditan rakyat memiliki non performing loan "tinggi", karena itu bank Indonesia meminta agar dalam penyaluran kredit dilakukan secara selektif, dan mematuhi ketentuan yang ada khususnya pemberian kredit kepada kelompok usaha tertentu, dan mengedepankan prinsip-prinsip kehati-hatian (prudential banking).

Size ditunjukkan dengan jumlah atau kapitalisasi asset, piutang, penjualan, modal dan elemen lain dalam laporan keuangan.
Makin besar kapitalisasinya makin besar ukuran perusahaan tersebut. Perusahaan dengan kapitalisasi asset kewajiban dan modalnya dianggap lebih mampu melakukan penjualan (memperoleh laba), lebih mampu dalam mendapatkan pinjaman dibandingkan dengan perusahaan kapitalisasi kecil. Biasanya yang digunakan sebagai ukuran perusahaan atau size adalah jumlah/ kapitalisasi total assets karena akan lebih mudah diidentifikasi. Perusahaan dengan asset besar pertumbuhan akan relatif besar dibandingkan dengan perusahaan kecil sehingga memiliki tingkat return yang lebih besar pula.

Rata-rata bank perkreditan rakyat di wilayah kota jakarta pusat, provinsi daerah khusus ibukota jaya, diatas diperoleh sebesar $98.11 \%$ pada bulan desember 2015 dan pada bulan maret 2016 mengalami peningkatan sebesar 101.83\%, pada bulan juni 2016 mengalami peningkatan kembali sebesar $110.14 \%$ dan kembali naik menjadi $112.07 \%$ pada bulan september 2016 . Size mengalami peningkatan kembali $122.58 \%$ pada bulan desember 2016.

Review penelitian dari 1. Agustiningrum, Riski tahun 2012, 2. Ulfawaty Adam tahun 2012 yang menunjukkan bahwa loan to deposit ratio berpengaruh positif signifikan terhadap profitabilitas, sedangkan 3. Bambang Sudiyatno \& Jati Suroso tahun 2010 hasil penelitian tentang loan to deposit ratio berpengaruh positif tetapi tidak signifikan terhadap kinerja keuangan yang diproksi dengan return on assets. Semakin tinggi loan to deposit ratio, maka laba bank semakin meningkat (dengan asumsi bank tersebut mampu menyalurkan kredit dengan efektif) (Sudiyatno, Bambang \& Suroso, Jati : 2010). Hasil penelitian mengenai capital adequacy ratio hasilnya berbeda-beda, penelitian yang dilakukan (Sudiyatno, Bambang \& Suroso, Jati : 2010) menyatakan capital adequacy ratio berpengaruh signifikan terhadap kinerja keuangan yang diproksi dengan return on assets. Sedangkan Agustiningrum, Riski tahun 2012 hasil uji menunjukan bahwa capital 
adequacy ratio berpengaruh tidak signifikan terhadap return on assets. Penelitian mengenai non performing loan yang di teliti oleh Agustiningrum, Riski tahun 2012 berpengaruh negatif signifikan terhadap return on assets.

Adapun alasan return on assets dipilih sebagai ukuran kinerja, dikarenakan return on assets digunakan untuk mengukur efektivitas perusahaan perbankan di dalam menghasilkan keuntungan dengan memanfaatkan aktiva yang dimilikinya. Return on assets merupakan rasio antara laba sebelum pajak terhadap total assets. Semakin besar return on assets menunjukkan kinerja keuangan yang semakin baik, karena return semakin besar.

Berdasarkan return on assets rata-rata dibandingkan dengan rata-rata loan to deposit ratio, capital adequacy ratio, non performing loan dan size untuk bank perkreditan rakyat yang terdaftar pada bank Indonesia pada periode triwulan mulai bulan desember 2015-2016 dapat dilihat pada tabel dibawah ini:

Tabel 1. Return On Assets, Loan to Deposit Ratio, Capital Adequacy Ratio, Non Performing Loan, Size, rata-rata yang terdaftar pada Bank Indonesia

\begin{tabular}{cccccc}
\hline Variabel & $\begin{array}{c}\text { Desember } \\
2015\end{array}$ & $\begin{array}{c}\text { Maret } \\
2016\end{array}$ & $\begin{array}{c}\text { Juni } \\
2016\end{array}$ & $\begin{array}{c}\text { September } \\
2016\end{array}$ & $\begin{array}{c}\text { Desember } \\
2016\end{array}$ \\
\hline$R O A$ & $2,69 \%$ & $4,23 \%$ & $2,15 \%$ & $3,23 \%$ & $4,62 \%$ \\
$L D R$ & $81,00 \%$ & $79,77 \%$ & $80,23 \%$ & $80,23 \%$ & $73,77 \%$ \\
$C A R$ & $24,08 \%$ & $23,38 \%$ & $21,38 \%$ & $20,85 \%$ & $22,00 \%$ \\
$N P L$ & $8,15 \%$ & $8,23 \%$ & $6,62 \%$ & $6,69 \%$ & $6,15 \%$ \\
SIZE & $98.11 \%$ & $101.83 \%$ & $110.14 \%$ & $112.07 \%$ & $122.58 \%$ \\
\hline
\end{tabular}

Sumber : Data Bank Indonesia yang diolah

Atas pertimbangan di atas, penulis ingin melakukan kajian untuk memastikan faktor-faktor yang mempengaruhi kinerja bank perkreditan rakyat seperti loan to deposit ratio, capital adequacy ratio, non performing loan dan size.

\section{Telaah Teori dan Pengembangan Hipotesis}

\section{Pengaruh Loan to Deposit Ratio terhadap} Return On Assets Bank Perkreditan Rakyat

Agustiningrum, Riski tahun 2012 meneliti tentang analisis pengaruh capital adequacy ratio, non performing loan, dan loan to deposit ratio terhadap profitabilitas pada perusahaan perbankan. Penelitian ini dilakukan di perusahan perbankan di bursa efek Indonesia periode 20092011. Pemecahan masalah menggunakan teknik analisis regresi linier ganda, Secara parsial loan to deposit ratio berpengaruh positif signifikan terhadap return on assets. Hal ini sesuai dengan penelitian 4. Hardiyani tahun 2011 meneliti tentang pengaruh capital adequacy ratio, non performing loan, dan loan to deposit ratio terhadap return on assets pada bank badan usaha milik negara yang go-publik di Indonesia (tahun 2006-2010). Hasil penelitian diperoleh secara parsial loan to deposit ratio berpengaruh positif dan signifikan terhadap return on assets dan pemecahan masalah menggunakan teknik analisis regresi linier ganda. Penelitian yang dilakuan 5. Nusantara Buyung Ahmad tahun 2009 meneliti tentang analisis pengaruh non performing loan, capital adequacy ratio, loan to deposit ratio dan biaya operasional/ pendapatan operasional terhadap profitabilitas bank (perbandingan bank umum go publik di Indonesia periode tahun 2005-2007). Hasil temuan untuk bank go public, secara parsial loan to deposit ratio juga berpengaruh signifikan positif terhadap return on assets dan pemecahan masalah menggunakan teknik analisis regresi linier ganda. 
H1: Loan to deposit ratio berpengaruh signifikan terhadap return on assets bank perkreditan rakyat.

\section{Pengaruh Capital Adecuacy Ratio terhadap Return On Assets Bank Perkreditan Rakyat}

Penelitian yang dilakukan Sudiyatno, Bambang \& Suroso, Jati tahun 2010 meneliti tentang analisis pengaruh dana pihak ketiga, capital adequacy ratio dan loan to deposit ratio terhadap kinerja keuangan pada sektor perbankan yang go public di bursa efek Indonesia pada periode 2005-2008. Capital adequacy ratio berpengaruh signifikan terhadap kinerja bank (return on assets). Sama juga dengan hasil penelitian dilakukan 6. Kunto Wibisono tahun 2011 meneliti tentang pengaruh capital adequacy ratio, NIM, Loan to deposit ratio dan non performing loan terhadap return on assets pada bank umum swasta nasional Indonesia. Capital adequacy ratio berpengaruh signifikan dan positif terhadap return on assets. Penelitian ini juga didukung oleh hasil penelitian 7. Laila Suci Amalia \& A. Mulyo Hariyanto tahun 2010. Meneliti tentang pengaruh capital adequacy ratio, non performing loan, NIM, biaya operasional/pendapatan operasional dan PPAP terhadap kinerja rentabilitas bank, studi kasus pada bank devisa dan bank non devisa tahun 2004-2008. Hasil penelitian diperoleh secara parsial capital adequacy ratio berpengaruh signifikan dan positif terhadap return on assets.

Berdasarkan uraian di atas, maka hipotesis alternatif yang diajukan untuk penelitian ini adalah sebagai berikut:

H2: Capital adequacy ratio berpengaruh signifikan terhadap return on assets bank perkreditan rakyat.

\section{Pengaruh Non Performing Loan terhadap Return On Assets Bank Perkreditan Rakyat}

Hasil penelitian 8. Adam Ulfawaty tahun 2013 meneliti tentang pengaruh non performing loan dan biaya operasional/pendapatan operasional terhadap profitabilitas bank (terhadap return on assets). Penelitian pada bank bank negara Indonesia, terbuka periode 20002011. Variabel non performing loan menunjukan adanya pengaruh signifikan terhadap return on assets. 9. Darmansyah tahun 2014 meneliti tentang pengaruh capital adequacy ratio, loan to deposit ratio, non performing loan, operational cost ratio dan net interest margin terhadap return on assets (studi empiris pada perusahaan perbankan di bei periode 2007-2012). Non performing loan pada penelitian ini mempunyai pengaruh negatif yang signifikan terhadap return on assets. Hasil penelitian ini juga sesuai dengan penelitian yang dilakukan oleh 10 . Pandu Mahardin tahun 2008, meneliti tentang analisis pengaruh rasio capital adequacy ratio, biaya operasional/pendapatan operasional, non performing loan, NIM dan loan to deposit ratio terhadap kinerja keuangan perbankan (studi kasus perusahaan perbankan yang tercatat di bursa efek Jakarta periode juni 2002-juni 2007). Non performing loan memiliki pengaruh negatif tetapi tidak signifikan.

Berdasarkan uraian di atas, maka hipotesis alternatif yang diajukan untuk penelitian ini adalah sebagai berikut:

H3: Non performing loan berpengaruh signifikan terhadap return on assets bank perkreditan rakyat.

\section{Metode Penelitian}

Penelitian ini menggunakan metode penelitian eksplanasi, merupakan penelitian yang dilakukan untuk menjelaskan kedudukan variabel-variabel yang diteliti serta hubungan satu variabel dengan variabel yang lain. Jenis ataupun tipe penelitian adalah deskriptif asosiatif yang bertujuan untuk memberikan gambaran dari variabel-variabel yang diteliti dan untuk mengetahui hubungan antara variabel melalui pengujian hipotesis, sedangkan kategori penelitian ini termasuk kedalam jenis penelitian kuantitatif yang mana data kuntitatif tersebut adalah data sekunder. Populasi yang digunakan dalam penelitian ini adalah seluruh perusahaan 
bank perkreditan rakyat yang terdaftar di bank Indonesia, periode desember 2015- desember 2016 ada sebanyak 13 bank perkreditan rakyat yang terdaftar di bank Indonesia. Pengambilan sampel yang digunakan adalah purposive sampling yaitu teknik penentuan sampel dengan pertimbangan khusus, sehingga layak dijadikan sampel. Sesuai dengan jenis data yang diperlukan yakni data sekunder, maka metode pengumpulan data yang digunakan adalah teknik observasi dengan menggunakan dokumentasi berdasarkan laporan keuangan yang dipublikasikan oleh bank Indonesia selama periode periode desember 2015-desember 2016.

Adapun kriteria yang menjadi pertimbangan dalam pengambilan sampel adalah sebagai berikut :

1. Bank perkreditan rakyat dan atau terdaftar di bank Indonesia periode desember 2015 desember 2016.

2. Memberikan laporan keuangan perusahaan secara konsisten selama periode penelitian.

3. Laporan keuangan berakhir per-triwulan.

Tabel 2. Definisi Operasional dan Variabel

\begin{tabular}{|c|c|c|c|}
\hline Variabel & Definisi Operasional & Rumus & Skala \\
\hline $\begin{array}{l}\boldsymbol{R O A}(\mathbf{Y}) \\
\text { Surat Edaran (SE) } \\
\text { Bank Indonesia } \\
\text { No.13/24/DPNP } \\
\text { Tanggal } 25 \text { Okrober } \\
2011\end{array}$ & $\begin{array}{l}\text { Rasio ini mengukur } \\
\text { efektivitas perusahan } \\
\text { perbankan menghasilkan } \\
\text { keuntungan dengan } \\
\text { memanfaatkan total aset } \\
\text { yang dimiliki }\end{array}$ & $R O A=\frac{\text { Laba Sebelum Pajak }}{\text { Total Aktiva }} 100 \%$ & Rasio \\
\hline $\begin{array}{l}\boldsymbol{L D R}\left(\mathbf{X}_{\mathbf{1}}\right) \\
\text { Surat Edaran }(\mathrm{SE}) \\
\text { Bank Indonesia } \\
\text { No.13/3/DPNP } \\
\text { Tanggal } 16 \\
\text { Desember } 2011\end{array}$ & $\begin{array}{l}\text { Rasio ini untuk } \\
\text { menggukur kemampuan } \\
\text { bank dalam memenuhi } \\
\text { kewajibannya kepada } \\
\text { para deposan serta dapat } \\
\text { memenuhi permohonan } \\
\text { kredit yang diajukan }\end{array}$ & $L D R=\frac{\text { Jumlah Kredit yng diberikan }}{\text { Total Dana Pihak Ketiga }}$ & Rasio \\
\hline $\begin{array}{l}\boldsymbol{C A R}\left(\mathbf{X}_{2}\right) \\
\text { Surat Edaran }(\mathrm{SE}) \\
\text { Bank Indonesia } \\
\text { No.12/11/DPNP } \\
\text { tertanggal } 31 \text { maret } \\
2010\end{array}$ & $\begin{array}{l}\text { Rasio ini menunjukan } \\
\text { kemampuan bank } \\
\text { meyediakan modal } \\
\text { sendiri }\end{array}$ & $C A R=\frac{\text { Modal Bank }}{\text { ATMR }} \times 100 \%$ & Rasio \\
\hline $\begin{array}{l}\text { NPL }\left(\boldsymbol{X}_{3}\right) \\
\text { Selamet Riyadi } \\
(2009) \text { dan SE BI } \\
\text { No.6/73/INTERN } \\
\text { DPNP }\end{array}$ & $\begin{array}{l}\text { Rasio ini untuk } \\
\text { mengukur seberapa } \\
\text { besar kredit bermasalah } \\
\text { yang dihadapi suatu } \\
\text { bank }\end{array}$ & $N P L=\frac{\text { Total Kredit Bermasalah }}{\text { Total Kredit }} \times 100 \%$ & Rasio \\
\hline
\end{tabular}

Sumber : Konsep penelitian yang diolah dari berbagai jurnal

Teknik analisis data dilakukan dengan uji regresi berganda. Pengujian regresi berganda dilakukan setelah uji asumsi klasik yang terdiri dari uji normalitas, uji multikolinearitas, uji heteroskedastisitas, dan uji autokorelasi. Uji normalitas dilakukan dengna uji kolmomogorov smirnov. Uji multikolinearitas dilakukan dengan melihat angka VIF (Variance Inflation Factor). Uji heteroskedasitas menggunakan uji Gletjser. Uji autokorelasi dilakukan dengen membanding 
nilai Durbin Watson (DW) dengan nilai DWtabel (du-(4-du)).

Analisis deskriptif digunakan mendeskripsi variable. Uji Koefisien Determinasi (Adjusted $R$ Square) digunakan untuk menilai seberapa dekat garis regresi yang terestimasi dengan data sesungguhnya (Nachrowi, 2006). Nilai Koefisien Determinasi mencerminkan seberapa besar variasi dari variabel terikat $Y$ dapat diterangkan oleh variabel bebas $\mathrm{X}$. Bila nilai Koefisien Determinasi sama dengan $0\left(\mathrm{R}^{2}=0\right)$, artinya variasi dari $\mathrm{Y}$ tidak dapat diterangkan oleh $\mathrm{X}$ sama sekali, bila $R^{2}=1$, artinya variasi dari $Y$ secara kesuruhan dapat diterangkan oleh $\mathrm{X} . \mathrm{R}^{2}$ mempunyai nilai antara nol dan satu. Pengujian hipotesis $_{1}$ sampai hipotesis ${ }_{3}$ dilakukan dengan melihat hasil uji-t. Jika hasil uji t menunjukkan nilai signifikansi $<0.05$ (pada $\alpha=5 \%$ ) maka hipotesis penelitian terbukti $\left(\mathrm{H}_{\mathrm{o}}\right.$ ditolak dan $\mathrm{H}_{1}$ diterima).

\section{Analisis Hasil dan Pembahasan}

Penelitian ini bertujuan untuk menganalisis pengaruh capital adequacy ratio, nonperforming loan, loan to deposit ratio, dan size terhadap return on asset. Sample dianalisis sejumlah 65 data bank perkreditan rakyat yang terdaftar di bank Indonesia per triwulan periode desember 2015-desember 2016.

Hasil uji asumsi klasik menunjukkan distribusi nilai residual variabel adalah normal $(0,518>0.05)$. Hasil uji multikolinearitas menunjukkan semua nilai variabel memiliki nilai variance inflation factor $<10$. Hasil uji Gletsjer menunjukkan nilai signifikasi $>0,05$ untuk seluruh pengaruh variabel independen terhadap nilai absolut residualnya. Nilai $\mathrm{DW}=$ 1,750 nilai tersebut berada diantara nilai 4-dU $=$ 2,466 dan 4-dL = 2,654.

Hasil uji Deskripsi variabel penelitian dirangkum pada tebel berikut.

Tabel 3. Deskripsi variabel penelitian

\begin{tabular}{lrrrr}
\hline Keterangan & $\begin{array}{l}\text { Loan to } \\
\text { deposit ratio }\end{array}$ & $\begin{array}{l}\text { Capital } \\
\text { adequacy } \\
\text { ratio }\end{array}$ & $\begin{array}{l}\text { Non } \\
\text { performing } \\
\text { loan }\end{array}$ & $\begin{array}{l}\text { Return } \\
\text { on assets }\end{array}$ \\
\hline Mean & 79,000 & 22,339 & 7,169 & 3,385 \\
\hline Median & 80.0000 & 18.0000 & 5.0000 & 2.0000 \\
\hline Std. Deviation & 13,729 & 11,154 & 6,133 & 7,539 \\
\hline Min & 44,00 & 6,00 & .00 & $-14,00$ \\
\hline Max & 103,00 & 59,00 & 22,00 & 27,00 \\
\hline
\end{tabular}

Hasil pengujian model peneltian dan hipotesis terangkum pada tabel berikut:

Tabel 4. Rangkuman Hasil Pengujian

\begin{tabular}{lrrrc}
\hline Keterangan & \multicolumn{1}{c}{ B } & Std. Error & \multicolumn{1}{c}{ t-hitung } & \multicolumn{1}{c}{ Sig. } \\
\hline Loan to deposit ratio & -.600 & .129 & $-4,640$ & .000 \\
Capital adequacy ratio & .414 & .072 & 5,748 & .000 \\
Non performing loan & .228 & .054 & 4,215 & .000 \\
Size & 0,008 & & & \\
Constant & $-19,565$ & 4,773 & $-4,099$ & .000 \\
R-Square & .439 & & & \\
Adjusted R-Square & .411 & & & \\
t-hitung & -4.099 & & & \\
Sig. F & 0.000 & & & \\
\hline
\end{tabular}


Berdasarkan tabel 4 diatas, maka dapat diperoleh persamaan regresi sebagai berikut:

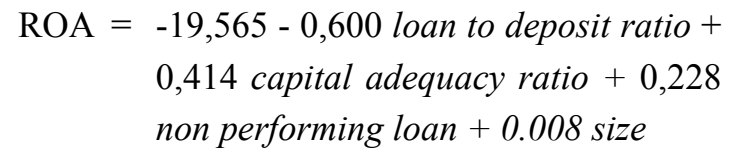

\section{Pengaruh Loan to Deposit Ratio, Capital Adequacy Ratio, Non Performing Loan dan Size terhadap Return on Assets secara parsial.}

Berdasarkan rumusan masalah, maka penelitian melakukan uji $\mathrm{t}$ (pengujian secara parsial). Pegujian secara parsial variabel loan to deposit ratio terbukti berpengaruh signifikan positif terhadap variabel return on asset. Hal ini terlihat dari nilai signifikan 0,000 lebih besar dari 0,05 dan pada t hitung $=-4,640$ lebih kecil dari t tabel $=2,30$. Dengan demikian hipotesis pertama yang menyatakan bahwa loan to deposit ratio memiliki pengaruh signifikan positif terhadap return on assets diterima. Hasil penelitian ini tidak sesuai dengan konsep dan logika kegiatan operasi bank, dimana semakin banyak dana pihak ketiga yang dapat dihimpun dari masyarakat, maka semakin besar peluang untuk mendapatkan return dari penggunaan dana tersebut. Hasil penelitian ini juga bertolak belakang dengan hasil penelitian Bambang Sudiyatno \& Jati Suroso tahun 2010 upaya yang dapat dilakukan oleh manajemen untuk meningkatkan kinerja bank (return on assets) dengan meningkatkan dana pihak ketiga dengan menghimpun dana dari masyarakat sebanyakbanyaknya.

Namun peneliti berpendapat atas hasil penelitian ini, bahwa bank perkreditan rakyat tidak hanya menjaga loan to deposit ratio berada pada zona aman, karena loan to deposit ratio yang baik tidak secara otomatis return on assets akan baik pula. Akan tetapi dengan loan to deposit ratio bank perkreditan yang baik, bank perkreditan rakyat harus berupaya untuk mendistribusikan dana pihak ketiga yang telah dihimpun kepada masyarkat menengah kebawah (sesuai dengan sasaran bank perkreditan rakyat), berupa pemberian pinjaman untuk modal usaha, modal investasi dan juga yang bersifat konsumtif dan tetap memperhatikan prinsipprinsip pemberian kredit yaitu prinsip kehatihatian (prudential of banking)

Variabel capital adequacy ratio tidak terbukti mempunyai pengaruh positif signifikan terhadap variabel return on assets. Hal ini terlihat dari nilai signifikan 0,000 lebih kecil dari 0,05 dan pada thitung $=5,748$ lebih besar dari $\mathrm{t}$ tabel $=2,30$. Dengan demikian hipotesis kedua yang menyatakan bahwa capital adequacy ratio memiliki pengaruh signifikan positif terhadap return on assets ditolak. Hasil penelitian ini bertolak belakang dengan penelitian Bambang \& Jati hasil penelitiannya diperoleh capital adequacy ratio berpengaruh positifdan signifikan terhadap keuangan bank (return on assets) dan bertolak belakang juga dengan konsep dan logika operasi bank, dan teori likuiditas bank. Upaya yang dapat dilakukan oleh bank perkreditan rakyat untuk meningkatkan kinerja bank (return on assets) adalah dengan menambah jumlah dana melalui subordinasi pinjaman atau setoran modal pemilik.

Demikian juga dari hasil penelitian variabel yang kedua, yaitu : capital adequacy ratio yang baik tidak serta merta membuat return on asset akan baik pula, atau dengan kata lain dengan penambahan modal inti atau modal sekunder oleh pemilik bank perkreditan rakyat atau pemilik saham bank perkreditan rakyat tidak secara lansung menaikkan retrun (laba) bank perkreditan rakyat tersebut, namun akan meningkat likuiditas bank perkreditan rakyat tersebut. Akan tetapi dengan modal bank perkreditan yang baik, dapat digunakan untuk menambahkan dana dalam pemberian pinjaman kepada masyarakat ataupun konsumen dan pemberian pinjaman tersebut juga harus tetap memperhatikan prinsip kehati-hatian (prudential of banking).

Variabel non performing loan terbukti mempunyai pengaruh positif signifikan terhadap variabel return on assets. Hal ini terlihat dari nilai signifikan 0,000 lebih kecil dari 0,05 dan 
pada $\mathrm{t}$ hitung $=4,215$ lebih besar dari t tabel $=2,30$. Dengan demikian hipotesis ketiga yang menyatakan bahwa non performing loan memiliki pengaruh signifikan negatif terhadap return on assets diterima. Non performing loan mencerminkan risiko kredit, dimana semakin kecil non performing loan akan menyebabkan naiknya pendapatan bunga, sehingga laba perusahaan meningkat. Sebaliknya tingginya non performing loan akan mengakibatkan naiknya tunggakan bunga kredityang berpotensi turunnya pendapatan bunga, sehingga laba perusahaan ikut menurun. Dengan demikian hasil penelitian ini membuktikan adanya pengaruh antara non performing loan terhadap return on assets dan didukung dengan hasil penelitian yang telah dilakukan oleh Ulfawaty Adam tahun 2013 yang menyatakan adanya pengaruh signifikan non performing loan terhadap return on assets.

Hasil penelitian dengan variabel yang ketiga, yaitu : non performing loan bank perkreditan yang baik akan menghasilkan return on assets bank perkreditan baik pula, atau dengan kata lain semakin sedikit kredit yang menunggak ataupun yang macet pada bank perkreditan akan meningkatkan return (laba) bank perkreditan rakyat khususnya pada bank perkreditan yang diteliti, maka dengan demikian dalam pemberian kredit pada bank perkreditan rakyat harus mengedepankan prinsip-prinsip kehatihatian (prudential of banking) dalam pemberian kredit kepada konsumen ataupun masyarakat yang memerlukan dana baik untuk modal usaha, modal investasi dan untuk konsumtip. Prinsipprinsip kehatian-hatian ini di mulai sejak konsumen mengajukan permohonan kredit ke bank perkreditan rakyat, verifikasi data termasuk bank Indonesia-checking, survey (usaha dan jaminan tambahan), analisis data, keputusan komite kredit, penandatangan perjanjian kredit, pengawasan kredit (monitoring credit), penagihan dan penyelesaian kredit bermasalah atau macet.

\section{Simpulan, Keterbatasan dan Implikasi Hasil Penelitian}

Simpulan hasil penelitian, variabel loan to deposit ratio tidak terbukti berpengaruh signifikan positif terhadap variabel return on asset. Para pemilik bank perkreditan rakyat menganggap bahwa dengan semakin tingginya loan to deposit ratio yang ditetapkan oleh bank, maka akan memiliki dampak yang lebih kecil pada likuditas, sehingga prospek pertumbuhan bank kedepan menjadi lebih kecil. Berdasarkan hasil penelitian, capital adequacy ratio tidak terbukti mempunyai pengaruh positif signifikan terhadap variabel return on assets. Kemungkinan hal ini dikarenakan peraturan bank Indonesia yang mengharuskan capital adequacy ratio minimal $8 \%$ mengakibatkan bank-bank perkreditan rakyat menjaga capital adequacy ratio yang dimiliki sesuai dengan peraturan.

Capital adequacy ratio bank perkreditan rakyat tidak berdampak terhadap kinerja keuangan, dengan kata lain dengan pemenuhan modal oleh pemilik bank perkreditan rakyat tidak serta-merta menaikkan return (laba) bank perkreditan rakyat, akan tetapi dengan baiknya capital adequacy ratio suatu bank perkreditan rakyat, maka bank perkreditan rakyat tersebut dapat menjaga likuiditasnya, bank perkreditan rakyat tersebut juga dapat menyerap kerugiankerugian karena modal juga harus dicadangkan terhadap hal-hal yang tidak terduga. Selain itu, hal ini juga dapat terjadi dikarenakan pada penelitian ada faktor-faktor lain yang mempengaruhi nilai capital adequacy ratio bank-bank perkreditan rakyat. Faktor itu antara lain faktor ekstern dan intern.

Berdasarkan hasil penelitian, non performing loan bank perkreditan rakyat terbukti mempunyai pengaruh negatif signifikan terhadap variabel return on assets bank perkreditan. Non performing loan bank perkreditan rakyat (sesuai aturan bank Indonesia dibawah 5\% kategori baik) berdampak langsung terhadap kinerja keuangan bank perkreditan rakyat terutama 
return (laba), hal ini jelas terlihat dari pendapatan bunga bank perkreditan rakyat ( $80 \%$ pendapatan bank perkreditan rakyat berasal dari pendapatan bunga kredit). Jika tagihan kredit baik pokok maupun bunga kredit tidak berjalan lancar dan sampai macet (menjadi non performing loan sesuai kategori kredit macet yang ditetap bank Indonesia), maka pendapatan bunga atas kredit tersebut tidak bisa dibukukan maka return atas bunga tersebut akan berkurang, sehingga return on assets akan turun. Dengan demikian diharapkan pada bank perkreditan rakyat di Indonesia, khususnya bank perkreditan rakyat yang berada di wilayah Provinsi Daerah Khusus Ibukota Jaya, agar menangani kredit dengan sebaik mungkin. Dari hasil penelitian bahwa hubungan antara variable size terhadap variable $\mathrm{Y}$ “sangat lemah", sedangkan pengaruhnya adalah sebesar 0.000 , yang artinya variable size tidak berfungsi sebagai variable kontrol.

Implikasi hasil penelitian untuk bank perkreditan rakyat yang ada di Indonesia khususnya yang berada di wilayah provinsi daerah khusus ibukota jaya perlu merumuskan strategi, meningkatkan kinerja banknya agar dapat lebih meningkatkan labanya dimasa yang akan datang.

\section{Daftar Referensi}

Anta Suryani \& Suhadak. (2016). Pengaruh rasio capital adequacy ratio, biaya operasional per pendapatan operasional, loan to deposit ratio, net interest margin dan non performing loan terhadap return on assets (studi kasus bank umum yang terdaftar di bursa efek Indonesia periode 2012-2014), Jurnal Administrasi Bisnis (JAB), Vol. 33, No. 1, April.

Azwir \& Yacub. (2006). Analisis pengaruh kecukupan modal, efisiensi, likuiditas, NPL, dan PPAP terhadap ROA Bank. Tesis prongram studi Magister Manajemen Program Pascsarjana Universitas Diponegoro, Dipublikasikan.
Sudiyatno Bambang \& Suroso Jati. 2010. Analisis pengaruh dana pihak ketiga, BOPO, CAR dan LDR terhadap kinerja keuangan pada sektor perbankan yang go public di bursa efek Indonesia (Periode 2005-2008). Jurnal Dinamika Keuangan dan Perbankan.Vol.2, no2.

Rosmnia Desti. (2014). Pengaruh Capital Adequacy Ratio (CAR), dan Non Performing Loan (NPL) terhadap Return On Asset (ROA) (Survei pada Perusahaan BUMN yang terdaftar di Bursa Efek Indonesia periode 2007-2014) Jurnal.

Hidayati Yuvia. (2015). Pengaruh Capital Adequacy Ratio (CAR), Net Interest Margin (NIM), Loan To Deposit Ratio (LDR) dan Non Performing Loan (NPL) terhadap Return On Assets (ROA) pada PT. Bank Mandiri (Persero) Tbk. Holictic Journal of Management Research.Vol.3, no2, Agustus.

Ayu Kadek \& Ari Nyoman. (2014). Pengaruh Capital Adequacy Ratio (CAR), Loan To Deposit Ratio (LDR), dan Perbandingan Biaya Operasional dengan Pendapatan Operasional (BOPO) terhadap Return On Asset (ROA) pada Bank Umum yang terdaftar di Bursa Efek Indonesia tahun 2008-2012) E-jurnal S1 Ak UPG,Vol. 2, No. 1.

Marwadi, Wisnu. (2005). Analisis faktor-faktor yang mempengaruhi kinerja keuangan bank umum di Indonesia (studi kasus pada bank umum dengan total asset kurang dari 1 triliun), Jurnal Bisnis strategi, Vol. 14, No. 1, Juli, pp. 83-94.

Meilinda Afriyanti \& Chabachib. (2009). Pengaruh faktor Current Ratio, Total Asset Turnover, Debt To Equity Ratio, Sales, Size terhadap Return On Asset (Studi pada perusahaan manufaktur yang terdaftar di bursa efek Indonesia tahun 2006-2009). Journal

Nita Puspita Sari. (2009). Evaluasi Kinerja Keuangan Bank dalam Kerangka Arsitektur Perbankan Indonesia Periode 2004-2008: 
Perbandingan CAR, NPL, LDR, EATAR, BOPO, dan ROA, jurnal Falkultas ekonomi Universitas Gunadharma.

Rahim, Rida \& Yuma Irpa. (2008). Analisa Efisiensi Operasional terhadap profitabilitas pada Bank Umum Syariah dan unit Syariah (Smum Syariah dan unit Syariah (Studi Kasus BSM dan BNI Syariah). Jurnal Bisnis \& Manajemen Vol. 4, No.3.

Agustiningrum Riski. (2012). Analisis Pengaruh CAR, NPL dan LDR Terhadap Profitibilitas pada Perusahan Perbankan periode 20092011. Jurnal falkultas Ekonomi Universitas Udayana (Unud).

Riyadi, Slamet. (2006). Banking Assets and Liability Management. Jakarta: lembaga Penerbit Fakultas Ekonomi Universitas Hasanudin, Makassar.

Setiadi, Pompong B. (2010). Analisis hubungan spread of interest rate, fee based income, dan loan to deposito ratio dengan ROA pada perbankan di Jawa Timur. Jurnal Mitra Ekonomi dan Manajemen Bisnis, Vol.1,No.1, april 2010, 63-82 Surabaya.
Sofyan, Sofriza. (2003). Pengaruh struktur pasar terhadap kinerja perbankan di Indonesia, Media Riset \& Manajemen, Vol.2, No.3, Desember, PP. 194-219.

Surat Edaran Bank Idonesia No.6/23/ DPNP Tanggal 31 Mei 2004, Perihal Sistem Penilaian Tingkat Kesehatan Bank Umum.

Surat Edaran Bank Idonesia No.6/23/ DPNP tanggal 24 desember 2004, Perihal Pedoman Sistem Penilaian Tingkat Kesehatan Bank Umum (CAMELS Rating).

Ulfawati Adam. (2012). Pengaruh Non Performing Loan (NPL) dan Biaya Operasional/Pendapatan Operasional (BOPO) terhadap profitabilitas Bank (ROA) pada BNI Periode 2000-2011. Jurnal Falkultas Ekonomi dan Bisnis Universitas Negeri Gorontalo.

Wicaksana, I Gede Ananditha, (2012). Pengaruh Cash Ratio, Debt to Equity Ratio, dan Return On Asset terhadap Kebijakan Deviden pada Perusahaan Manufaktur di Bursa Efek Indonesia, e-journal Udayana Denpasar. 